\title{
IOWA AND THE COPPERHEAD MOVEMENT
}

\author{
by David L. Lendt \\ Ames, lowa
}

David L. Lendt graduated from Iowa State University with a B.S. in Technical Journalism. Since that time he has edited three Iowa weekly newspapers and has been managing editor of three specialized journals in Des Moines. Since 1967, $\mathrm{Mr}$. Lendt has been slowly pursuing a M.A. degree in history at Iowa State. "Iowa and the Copperhead Movement" represents the beginning of a thesis that Mr. Lendt plans to further pursue. The paper was originally completed for one of Mr. Lendt's graduate courses at Iowa State.

Much has changed with the rewriting of the Civil War from the historical perspective afforded by the passage of more than 100 years. Lincoln has been realistically assessed as a diplomat and as a politician, the Radical Republicans' luster has become tarnished with the years and the "inevitability" of the war itself has been questioned. But the story of the Copperhead movement has undergone little change and the men who led the movement "are still viewed as men whose hearts were black, whose blood was yellow, and whose minds were blank."

${ }^{1}$ Frank L. Klement, The Copperheads in the Middle West (Chicago: The University of Chicago Press, 1960 ), p. vii. 
The Copperhead movement was centered in the middle west and, in particular, in the states of Ohio, Indiana, Michigan, Illinois and Wisconsin. Understandably, the Copperhead viewpoint also found expression in Iowa and the story of the Copperheads became a significant part of the state's history.

The Copperheads stood in direct opposition to Abraham Lincoln's administration and its prosecution of the war against the southern states. They decried the war as unnecessary and employed oratory, print and, eventually, terrorist tactics to frustrate the war effort and to make inoperable the machinery of the military draft. They have been described as traitors and the tactics of the most prominent Copperhead, Clement Vallandigham of Ohio, have been compared with those of Adolph Hitler. ${ }^{2}$

The reasons for the strength of the Copperheads in the middle west were many and complex, but economic considerations were important in the growth of the movement in Iowa and elsewhere, particularly in tandem with the depression of 1861-1862. The Mississippi River blockade, imposed by the War Department, had cut off southern markets for midwestern farm products and had contributed to depressed farm prices. Corn prices, for example, fell to 10 cents per bushel and farmers burned their corn for fuel rather than dispose of it at such low rates. ${ }^{3}$

With transportation to the south shut off, midwestern farmers looked to eastern markets to dispose of their agricultural surpluses and to the railroads to transport the products eastward. The railroads made the most of the opportunity by more than doubling freight rates in 1861 and adding further rate increases the following year. Iowans complained that it cost "more than five times as much to transport a bushel of wheat from Iowa to New York as the farmer received for it." 4

\footnotetext{
${ }^{2}$ Nathaniel Weyl, Treason: The Story of Disloyalty and Betrayal in American History (Washington: Public Affairs Press, [1950]), p. 287.

${ }^{3}$ Klement, op. cit., p. 3.

${ }^{4}$ Ibid., p. 10.
} 


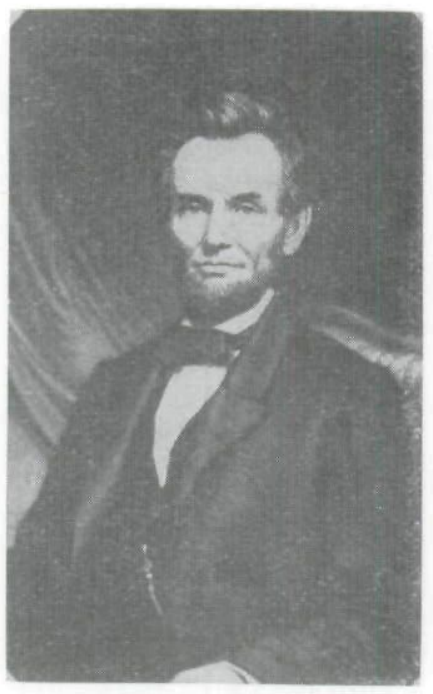

Abraham Lincoln

It became very easy for midwestern farmers, as well as for some businessmen throughout the Mississippi Valley, to blame the Lincoln administration for their economic plight. It was even easier for those of the Democratic faith to capitalize upon the hard times and to blame Lincoln and the Republicans for the nation's difficulties. Dennis A. Mahoney, editor of the Dubuque Herald and later one of the most outspoken of Lincoln's critics, in an article published November 23, 1860, had been quick to blame Lincoln for the state of affairs. "Grain has gone down till it won't pay hauling charges," he wrote, "So much for electing a man-the exponent of Personal Liberty Bills, Nigger Suffrage and Equality, Beecherism, Stoweism, Niggerism and a dozen isms and Tom fooleries upon which the entire North under the lead of Abolitionized Massachussetts has gone mad."

Mahoney's use of racism in promoting his point of view was typical of those Democrats who had discovered that the powerful prejudice enjoyed widespread popularity throughout the midwest. Irish - a large number of whom in Dubuque considered Mahoney their leader-and German-Americans in the cities were inclined to vote the straight Democratic ticket as the best defense of their jobs. They feared that hordes of emancipated slaves, freed by the abolitionist administration, would move north to flood the labor market and to compete for the lowly jobs the immigrants then held. Southern immigrants to Iowa also brought their racial prejudices and their Democratic ties with them to the small homesteads on the poor southern Iowa soil where most made their homes.

\footnotetext{
${ }^{5}$ Quoted in Klement, op. cit., p. 5.
} 
Mahoney's dislike for the Republican Party was compounded by his personal financial difficulties. As early as October 19, 1858, a notice appeared in the Dubuque Express and Herald drawing attention to the newspaper's economic plight.

Our readers will perceive, without being told of it, that the Daily has been shorn of considerable of its size. This is consequent upon the falling off of the business of the city and country. When business increases, the Herald will take its old dimensions. ${ }^{6}$

In a letter to Charles A. Mason, dated February 9, 1860, Mahoney declined a committee clerkship in Washington, D.C., as patronage for his efforts in the Democrats' behalf. Mahoney had solicited the offer, but was not satisfied that it was the answer to his woes.

If such a thing could be procured as an executive appointment, either as a consul or in one of the territories, it would suit me much better; for to tell you the truth, having lost all I had, some $\$ 40,000$ in the crash which has ruined so many in Iowa, I would be glad to have an opportunity of beginning anew in a field of enterprise. Could I but do this under a government appointment for even a little while, I feel that I could to some extent, recover myself both in health and fortune. ${ }^{7}$

The Copperhead movement, which raised its head from the swollen ranks of the disenchanted Democratic party, was comprised of the poor and the unskilled. It was a fighting alliance forged between the poor farmers who had moved to the middle west from the South and the immigrant workers who had moved west from the slums of the Atlantic Seaboard cities $^{8}$

Vallandigham - the leader of the alliance-had served in the Ohio state legislature and, as a member of the U.S. Congress, had been a vicious opponent of President Lincoln. $\mathrm{He}$ had also been active in the Knights of the Golden Circle, a secret organization of southern sympathizers in the north. The strength of the Knights of the Golden Circle was in the south, although its roots were found in Vallandigham's Ohio. Its founder, Dr. George William Lamb Bickley, member of

${ }^{6}$ Article, Dubuque Express and Herald, Oct. 19, 1858, p. 2.

${ }^{7}$ Letter, D. A. Mahoney to C. A. Mason, Feb. 9, 1860, Iowa State Department of History and Archives, Charles A. Mason Collection, Vol. III.

${ }^{8}$ Weyl, op. cit., p. 284. 
an old Virginia family, had become fascinated with the "Manifest Destiny" of the United States to seize and dominate the entire continent. His new secret order was intended to provide a force-the American Legion-to colonize and Americanize the northernmost provinces of Mexico. ${ }^{9}$ In 1854, he organized the first castle (local chapter) of the K.G.C. in Cincinnati, Ohio-the city already accorded the dubious distinction of being the birthplace of the Know-Nothings and the scene of antiforeign riots. ${ }^{10}$

As the movement spread northward, it became the organization of the Peace Democrats who disapproved of the Civil War and its castles made their way into Iowa. A strong chapter of the K.G.C. operated in Poweshiek County, ${ }^{11}$ the existence of a group as far north as Floyd County was rumored and the United States Marshal in Des Moines received evidence that the Knights were running military supplies to insurrectionists in Missouri. ${ }^{12}$

In the Democratic Irish mining section around Dubuque, it was asserted that men were having their homes burned for enlisting in the Union Army. ${ }^{13}$ In Poweshiek County, two marshals were shot down from ambush as they led a posse in pursuit of two Iowans who had refused to submit to the military draft and had sought refuge with southern sympathizers. The most violent clash between Iowa Copperheads and officials took place near South English, in Keokuk County, in August, 1863. The encounter took the lives of several persons, including Cyphert Tally, a preacher and principal in the peace faction of the region. ${ }^{14}$ The Governor of Iowa was obliged to call out eleven companies of home guards to quell the battle, later known as the "Skunk River War" or "Tally's War".

${ }^{9}$ Wood Gray, The Hidden Civil War (New York: The Viking Press, 1941), p. 70.

${ }^{10}$ George Fort Milton, Abraham Lincoln and the Fifth Column (New York: Vanguard Press, 1942), p. 66.

${ }^{11}$ William J. Petersen, The Story of Iowa (4 vols., New York: Lewis Historical Publishing Company, Inc., 1952), I, p. 443.

${ }^{12}$ Gray, op. cit., p. 71.

${ }^{13}$ Ibid.

${ }^{14}$ Ibid., p. 164. 
Because disrepute was attached to the Knights following the war, former members were hesitant to provide accounts of the organization's activities in the state during the rebellion. For this reason, and because of the clandestine nature of the movement, the part played by the Knights of the Golden Circle in the few outbreaks of Copperhead violence in Iowa may never be confirmed. It was apparently assumed at the time, however, that the Knights or the Copperheads were behind every disruption, overt or covert, of the Union's ability to wage unfettered war against the South.

In the latter part of 1863, the K.G.C. became the Order of American Knights. In 1864, its name was changed to the Sons of Liberty, and Vallandigham was appointed its Supreme Commander. ${ }^{15}$

Feeling ran high in Iowa where some Republicans openly suggested that persons whose views implied sympathy for the Confederacy had deprived themselves of the protection of the laws. The Burlington Daily Hawk-Eye, speaking for the Republicans of Iowa, on August 23, 1861, published the following warning "To Whom It May Concern:"

It may be as well, perhaps to come to a definite understanding. This community, as well as many others, has for some time past tolerated a few individuals whose conversation has been such as to give reason to doubt their loyalty. . . . If they really sympathize with the rebellion they should go where they belong, to the rebel states. . . We have no disposition to draw down upon any man, or class of men, public indignation or violence. But we only give expression to the general feeling when we say that no man's personal safety can be assured for one moment after the conclusion shall have been clearly arrived at that he is a traitor. ${ }^{16}$

Dennis Mahoney, in a letter to Charles Mason, in June, 1861, thanked Mason for a letter he had sent and indicated that it had nearly found its way into the columns of the Herald. But, he added, "perhaps it is best that I did not, as the expression of such sentiments just now is regarded as an act of treason..." ${ }^{17}$

${ }^{15}$ Mark M. Boatner, III, The Civil War Dictionary (New York: David McKay Company, Incorporated, 1959), p. 466.

${ }_{6}^{1}$ Quoted in Gray, op. cit., p. 68.

${ }^{17}$ Letter, D. A. Mahoney to C. A. Mason, June 11, 1861, Iowa State Department of History and Archives, Charles A. Mason Collection, Vol. V. 
Although "Peace Democrats" and "Copperheads" were terms often applied interchangeably to those opposed to the Lincoln administration and to the Civil War, the line between those committed to a negotiated peace for the sake of saving lives and resisting social change and those committed to obstruction of the U.S. government for baser purposes is an often imperceptible one.

Some of these dissenters were loyal but some were openly in sympathy with the slave States. . . . These 'Peace Democrats' (sometimes in favor of peace at any price) were often called 'Copperheads,' either from a badge worn by some southern sympathizers, or in reference to the poisonous copperhead snake which, unlike the rattlesnake, struck without warning. ${ }^{18}$

The early protests of Copperhead leaders against the administration gained little attention and were all but submerged in the wave of nationalism which swept the north after the surrender of Fort Sumter. But, as the rebellion grew, as Union military mistakes were compounded and as the economic situation worsened, those in the north who were opposed to Lincoln's policies became more numerous and more outspoken.

Arbitrary arrests of individuals open in their opposition to the war gave the Copperheads a civil liberties plank upon which to mount their growing campaign. Vallandigham introduced a bill in Congress calling for the imprisonment of President Lincoln if the chief executive allowed any more arrests in the border states or in the loyal states. ${ }^{19}$

President Lincoln had determined, under the provision spelled out in the Constitution, Article I, Section 9, Paragraph 1 , that the privilege of the writ of habeas corpus could and should legally be suspended because, "I decided that we have a case of rebellion." ${ }^{20}$ The question of whether such authority belongs to Congress or to the President is one of the most famous and lively controversies in the history of the Constitution. Perhaps no other feature of the policy of the Lincoln administration was more openly criticized or more tenaciously defended and few have since been more widely debated by statesmen, editors, jurists and historians.

\footnotetext{
${ }^{18}$ Petersen, op. cit., p. 439.

19 Klement, op. cit., p. 18.

${ }^{20}$ James Garfield Randall, Constitutional Problems Under Lincoln (Urbana: University of Illinois Press, 1951), p. 122.
} 
In the early part of the war the withholding of the privilege of the habeas corpus writ was restricted to definite localities specified in various presidential proclamations, beginning with that of April 27, 1861, covering the line from Washington to Philadelphia. During this period prisoners taken under military orders were held under the custody of the Department of State. The emergency at this time was exceedingly grave and hundreds of prisoners were apprehended. ${ }^{21}$

Secretary of State William H. Seward, who was in charge of such arrests, conducted them on a scale which today seems incredible in that he assumed authority in areas which properly belonged under the jurisdiction of President Lincoln himself. Seward organized a secret service, the purpose of which was the apprehension of prisoners, although arrests were sometimes made by his confidential agents, local police, U.S. military authorities or marshals of the federal courts. ${ }^{22}$

In February, 1862, a sweeping order provided for the release of political prisoners and the control of political enemies was handed to the War Department. Until this time, the use of the suspension of the habeas corpus privilege had been rather limited, but the first measure of general scope touching the suspension of the Constitutional guarantee was taken September 24, 1862, when President Lincoln proclaimed that, during the rebellion, persons discouraging enlistment, resisting the draft or guilty of any disloyal practice were subject to martial law and liable to trial by courts-martial or military commissions. Furthermore, in such cases, the habeas corpus privilege was authorized to be suspended. ${ }^{23}$

Despite an outpouring of addresses, editorials and resolutions on the part of midwestern Democrats, a new wave of arrests was made throughout the nation's mid-section in August and September of 1862. Among those arrested in Iowa during this time, most had earned the wrath of H. M. Hoxie, the federal marshal who also happened to be a member of the Republican State Central Committee. ${ }^{24}$ Among the Iowans arrested were Dennis Mahoney, the fiery Dubuque editor, and Daniel Sheward, editor of the Fairfield Constitution and Union.

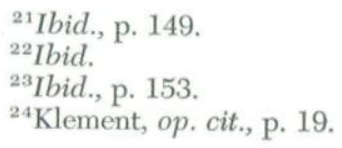


If the Democrats had been mistaken in their hope that their objections to Lincoln's policy of arbitrary arrests would result in a new respect for the writ of habeas corpus, the Republicans were mistaken if they thought additional arrests would silence their critics. It seemed to have become an honor to be incarcerated for voicing objection to the administration's infringement of civil liberties. Sheward's wife, in a letter dated September 3, 1862, wrote to her husband, "Oh, I tell you that your arrest is the greatest honor that they could confer upon you. I feel proud of the way that you was (sic) arrested and your friends think the same." In the same letter, she suggested, "If they keep you there for fear of your influence at the election, that won't win, for you have made more votes for the democrats by your arrest than if you had remained at home - so they won't make much in that respect." ${ }^{25}$

Mahoney was held in jail in Washington, D.C., for the last four months of 1862 without ever having been charged and without ever having been brought to trial. During the time he was imprisoned, he was nominated, in absentia, for a Congressional seat. ${ }^{26}$

The matter of arbitrary arrests was made a major issue of the 1862 elections by midwestern Democrats who interpreted the Republican election losses as a popular repudiation of arbitrary arrests and abolitionism. The most vocal critics of the Lincoln administration added to the President's embarrassment by staging heroes' welcomes for political prisoners freed soon after the votes had been counted. The Dubuque welcome for Dennis Mahoney was described by the Republican editor of the Dubuque Times as a "most preposterous, treasonable, and disgraceful exhibition." ${ }^{27}$

Midwestern Democrats, who were conservative in their attitudes toward change and who saw danger in the rapid alterations they saw being implemented by the Republican administration, had agreed with Vallandigham's interpretation

${ }^{25}$ Copy of Letter, Mrs. D. Sheward to D. Sheward, Sept. 23, 1862, Iowa State Department of History and Archives, Charles A. Mason Collection, Vol. VIII.

${ }^{26}$ Klement, op. cit., p. 20.

${ }^{27}$ Quoted in Klement, op. cit., p. 23. 
of the 1862 election results as a setback for the Lincoln administration and a victory for conservatism. But, when Lincoln, in his message to Congress December 1, 1862, made no concession to the election results, they repeated their claims that the election had repudiated radicalism and developed their slogan, "The Constitution as it is, the Union as it was."

Vallandigham, too, was accorded a hero's welcome when he returned as a defeated Congressman to Dayton, Ohio, in March 1863. Word of the welcome made its way to Cincinnati and to General Ambrose E. Burnside, who had just been assigned to command the Department of the Ohio. Burnside learned that the ovation accorded Vallandigham had featured two bands, thirty-four rounds from a cannon, deafening cheers, a noisy parade and much speechmaking aimed at insulting the President and his Ohio supporters. ${ }^{28}$

Burnside, who had faith in force and in the threat of force, had once called Vallandigham a "hyena" and had suggested that Vallandigham be hanged and "apologize if necessary afterward." ${ }^{29}$ Since Burnside believed that Copperhead speeches and editorials gave encouragement to the enemy, he issued the well-known "General Orders, No. 38" April 13, 1863, proclaiming that those who committed acts for the benefit of the enemy would be tried as spies or traitors and subject to military procedure, and eventually saw Vallandigham convicted of disobeying the edict.

Vallandigham was delivered to the Confederacy in order both to negate his bid for martyrdom and to stigmatize all criticism of the administration as traitorous. Lincoln himself ordered the banishment of Vallandigham at the suggestion of cabinet members. The Copperhead subsequently went to Nassau, then to Canada, from where he returned in June, 1863, when the Ohio Peace Democrats wrote into the state platform a provision favoring peace. ${ }^{30}$ General George Brinton McClellan repudiated the provision before accepting the party's nomination for the presidency at the Chicago convention in August. ${ }^{31}$

\footnotetext{
${ }^{28}$ Klement, op. cit., p. 23.

${ }^{29}$ Ibid.

${ }^{30}$ Milton, op. cit., p. 218.

${ }^{31}$ Boatner, op. cit., p. 625 .
} 
In contrast to the plank introduced by the Peace Democrats, the first resolution of the platform of the National Union (Republican) Convention accepted June 7, 1864, was a direct refutation of the Copperheads and all they stood for:

RESOLVED: That it is the highest duty of every American citizen to maintain against all enemies the integrity of the Union and the paramount authority of the Constitution and laws of the United States; and that, laying aside all differences of political opinion, we pledge ouselves as Union men, animated by a common sentiment and aiming at a common object, to do everything in our power to aid the Government in quelling by force of arms the rebellion now raging against its authority, and in bringing to the punishment due their crimes the rebels and traitors arrayed against it. ${ }^{32}$

The demise of the Copperheads was signaled by the 1864 Democratic Convention. Not only was the peace plank refuted, but a midwestern uprising of Copperheads, scheduled to coincide with the meeting of the party in Chicago, was a fiasco.

Vallandigham, whose return to American soil might have been interpreted as contempt for the President's order banishing him to the Confederacy, was allowed to remain free and, in fact, was in charge of the convention's drafting subcommittee in which role he eagerly attempted to make a peace plank part of the national platform. Although Lincoln's official biographers claim that Vallandigham's return to the United States came as a surprise to the President, there is evidence to suggest that it was no surprise at all and that Lincoln allowed the exiled Copperhead free rein in the hope that Vallandigham would help to divide the Democratic party. $^{33}$

The uprising which was to have taken place at the convention had as its short-run aim, the liberation and arming of Confederate prisoners held in Chicago, and as its long-run goal, a revolt of the Copperhead states and their eventual independence as an "empire of Northwestern States." ${ }^{34}$ The operation was under the direction of a Captain Thomas Hines, who had been appointed by the Confederate government to take charge of insurrection in the midwest. He and a detach-

\footnotetext{
${ }^{32}$ Henry Steele Commanger (ed.), Documents of American History, (8th ed., New York: Appleton-Century-Croft, 1968), p. 435.

${ }^{33}$ Milton, op. cit., p. 224.

${ }^{34}$ Ibid., p. 298.
} 
ment of seventy former Confederate soldiers were in Chicago when the Convention opened. In addition, local Copperheads were to organize and equip two regiments of men and leaders of the Sons of Liberty had promised to have 50,000 of their followers available for duty. Six thousand Confederate prisoners of war in Camp Douglas, Chicago, would form the hard core of the Copperhead army. ${ }^{35}$

Hines had little confidence in the ability of civilians to carry off the revolt and his judgment proved correct. To complicate matters, news of the arrests of Indiana Copperhead leaders had reached Chicago and "Copperhead courage was oozing." ${ }^{36}$ The great insurrection fell apart as spokesmen for the Sons of Liberty were howled down on the convention floor and Democrats hurriedly denounced the extremist faction. ${ }^{37}$

Because of the proximity to Chicago of Iowa's Copperheads along the Mississippi River, it might be assumed that Iowans played a role in laying the abortive Copperhead plans for the Democratic Convention of 1864. No such evidence was found and, because of the outcome of the scheme and subsequent events in the nation, any such evidence may have been destroyed by those who created it.

Following Lincoln's second election, and with the upturn in Union military successes, the fate of the Copperheads was virtually sealed. Southern sympathizers in the North turned to violence and destruction in their frantic last-ditch efforts to find outlets for their bitterness and victims of their revenge. Whether a direct connection existed between rampaging former soldiers of the Confederacy and the Copperheads, the connection was assumed and the name Copperhead became synonymous with traitor for years to come.

Although Iowa had a part in the Copperhead movement, there is little evidence to indicate that Copperhead leaders in Iowa had much influence in the events which finally discredited the organization. On the contrary, Iowa Copperheads whose names appear in the historical accounts of the political movement came largely from the ranks of the state's

${ }^{35}$ Weyl, op. cit., p. 298.

${ }^{36}$ Ibid.

${ }^{37}$ Ibid. 
Democratic newspaper editors and professional men who saw themselves as exponents of the "loyal opposition" and who attempted to make their appeal through the printed word and through the ballot box rather than through violence or lawlessness.

Iowans, other than editors, whose names were prominently associated with the Copperheads included George W. Jones, first U.S. Senator from Iowa, and Gideon S. Bailey, a former territorial and state legislator from Van Buren County, both of whom were imprisoned in a wave of arrests to satisfy complaints from families of Union soldiers. ${ }^{38}$

While minister to Colombia the previous winter and spring, Jones had written his college friend Jefferson Davis, and others, expressing sympathy for the South but urging that the Union be preserved. Solely on the basis of the contents of these intercepted letters, he was arrested December 20, 1861, following his return to the United States and was imprisoned at Fort Lafayette in New York, until February 22, $1862 .^{39} \mathrm{~A}$ man of tremendous influence and one whose life was a succession of fascinating events, Jones saw an exceptionally promising political carreer dissipate following his arrest.

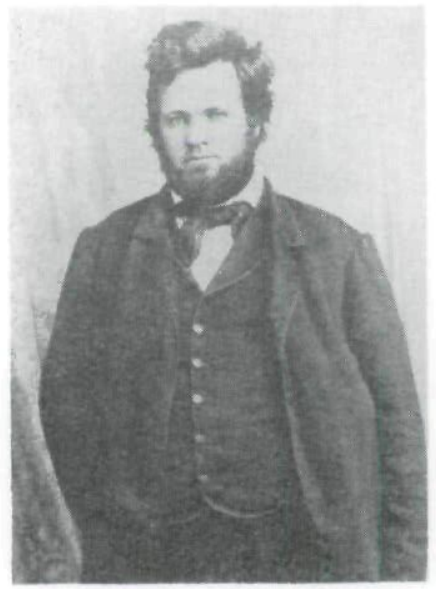

Henry Clay

Another was Henry Clay, "Dirty Shirt" Dean, a Methodist preacher and an orator. When the Methodist Episcopalian Church split in 1844, over the question of slavery, he retired from the ministry and turned to law. He was eventually mobbed and imprisoned because of his views concerning the war. ${ }^{40} \mathrm{He}$ also wrote an anti-administration book, The Crimes of the Civil War and the Curse of the Funding System, published in Baltimore in $1869 .{ }^{41}$

${ }^{38}$ Petersen, op. cit., p. 440.

${ }^{39}$ Gray, op. cit., p. 69.

${ }^{40}$ Petersen, op. cit., p. 439.

${ }^{41}$ Klement, op. cit., p. 330. 
Samuel F. B. Morse, inventor of the telegraph and an outspoken Peace Democrat, spearheaded a drive to establish a national Democratic propaganda agency for the purpose of "diffusing useful political knowledge." A contributor to his organization, The Society for the Diffusion of Political Knowledge, was Iowan Charles Mason who provided Address to the People of Iowa, four German-language tracts intended to keep Germans within the Democratic party. ${ }^{42}$ Mason was a successful lawyer and an active Democratic politician. A graduate of West Point, he was one member of the Class of 1829 who finished ahead of Robert E. Lee. ${ }^{43}$

Mason, in 1863, was nominated the Democratic candidate for Governor of Iowa. In nominating him, the convention resolved: "That our Union was formed in peace, and can never be perpetuated by force of arms, and that a republican government held together by the sword becomes a military despotism." ${ }^{\prime 4}$

LeGrand Byington, an embittered Democrat who had lost a two-year fight for a contested congressional seat, drafted a document entitled, Address of the Democratic State Central Committee to the People of Iowa, calling for a political reformation in the likeness of the Democratic party and claiming that the shadow of Jacobinism and the French Revolution had darkened the land. ${ }^{45}$

But no midwestern Copperhead worked more diligently in the area of publication than did Dennis Mahoney of Dubuque. During the time he was held a prisoner of the government, he turned to writing and publication for his revenge. Early after his release in 1863, he began an expose of the arbitrary arrests as one means of vindicating himself. He selected The Prisoner of State as the title of his 414-page book and went to New York to supervise its publication in

${ }^{42}$ Ibid., p. 104.

${ }^{43}$ Ibid., p. 327.

${ }^{44}$ Quoted in Gray, op. cit., p. 146.

${ }^{45}$ Klement, op. cit., p. 102. 
April, 1863, and to distribute the printed work. He dedicated the book to "Edwin M. Stanton, Secretary of War, U.S.A.", and, in the harshly-worded dedication stated, "I am, sir, one of the many hundred victims of the despotism of the arbitrary power of which you have become the willing, servile and pensioned tyrant." ${ }^{\text {"46 }}$

While the debate concerning The Prisoner of State replete with historical inaccuracies but constructed in readable fashion - continued, Mahoney stayed in New York to write a second anti-Lincoln book, The Four Acts of Despotism, in which he treated the Tax Bill, the Finance Bill, the Conscription Bill and the Indemnity Act as those most onerous to the American people. ${ }^{47}$

Mahoney had become nationally known for his criticism of the administration and he had become, for the moment, the Iowan most prominent in the Copperhead movement. But, following the war, Mahoney seems to have dropped into obscurity. Iowa became too strongly Republican for former Copperheads to flourish politically here; but, George Wallace Jones, despite a ruined political future, in time became an indulged and venerated early settler. "Dirty Shirt" Dean, who once enjoyed prestige and influence, would be remembered by Mark Twain in Life on the Mississippi, as an antiquated freak. ${ }^{48}$ The legacy of the Iowa Copperheads was an Iowa so overwhelmingly Republican that its people fell victim, with citizens of other midwestern states, to the eastern interests which the Copperheads had so feared and detested.

\section{BIBLIOGRAPHY}

BOOKS

Boatner, Mark M., III. The Civil War Dictionary. New York: David McKay Company, Inc., 1959.

Commoger, Henry Steele, ed., Documents of American History. 8th ed. New York: Appleton-Century-Crofts, 1968.

Gray, Wood, The Hidden Civil War: The Story of the Copperheads. New York: The Viking Press, 1942.

${ }^{46}$ Ibid. p. 101.

${ }^{47}$ Ibid., p. 102.

${ }^{48}$ Gray, op. cit., p. 220. 
Klement, Frank L., The Copperheads in the Middle West. Chicago: The University of Chicago Press, 1960.

Milton, George Fort, Abraham Lincoln and the Fifth Column. New York: The Vanguard Press, 1942.

Petersen, William J., The Story of Iowa. 4 vols. New York: Lewis Historical Publishing Co., Inc., 1952.

Randall, James Garfield, Constitutional Problems Under Lincoln. rev. ed. Urbana: University of Illinois Press, 1951.

Weyl, Nathaniel, Treason: The Story of Disloyalty and Betrayal in American History. Washington: Public Affairs Press, [1950].

\title{
MANUSCRIPTS
}

Iowa State Department of History and Archives, Des Moines. Charles A. Mason Letters.

NEWSPAPERS

Dubuque Express and Herald. Article, October 19, 1858.

\section{THE ESTES HOUSE}

\author{
by R. J. Bickel \\ Keokuk, lowa
}

This article was sent into the ANNALS office by Mr. James Bentley of Davenport, Iowa. Mr. Bentley has had a historical interest in the Keokuk area and in the Estes House for some time. The article itself was researched and written by Mr. R. J. Bickel of Keokuk who was a member of the Lee County Historical Society and who is now deceased.

Keokuk was in the midst of a spectacular boom in 1856 and during that period attracted dozens of wealthy easterners and southerners who saw in the rapidly expanding city the future metropolis of the middlewest. It was not surprising, therefore, that Rufus Wilsey undertook the construction of a $\$ 60,000$ hotel building the following year. In the spring of 1857 , Rufus Wilsey, Hawkins Taylor and man by the name of O'Harra organized a company to build a grand hotel, one that would be in keeping every way with the great future that seemed to be opening out before Keokuk. The corner of Main and Fifth Streets was selected for the proposed hotel, and $\$ 40,000$ was paid for 150 feet front. Mr. H. H. Belding publisher of the "Northwestern Review" in his July number of 1857 states: 
Copyright of Annals of Iowa is the property of State of Iowa, by \& through the State Historical Society of Iowa and its content may not be copied or emailed to multiple sites or posted to a listserv without the copyright holder's express written permission. However, users may print, download, or email articles for individual use. 